\title{
The in-vivo metabolism of C3 in ankylosing spondylitis
}

\author{
L. BRINCH, O. VINJE, P. TEISBERG, O. J. MELLBYE, AND I. AAKESSON \\ From the Medical Department 7, Ullevål Hospital; Oslo Sanitetsforenings Rheumatism Hospital; and the \\ Medical Department and Institute of Immunology and Rheumatology, the Rikshospital, Oslo, Norway
}

SUMMARY Turnover studies with radioactively labelled C3 were performed in 7 patients with ankylosing spondylitis and in 14 healthy individuals. As a group the patients had a moderately higher fractional catabolic rate of $\mathrm{C} 3$ than the controls. A possible explanation is that the complement system is activated by immune complexes. The serum levels of $\mathrm{C} 3$ were high. The hypercatabolism was therefore more than compensated for by an increased synthesis rate.

The aetiology and pathogenesis of ankylosing spondylitis (AS) is unknown. Studies on the role of the immune system have suggested that both cellular and humoral immunity may be involved, but a clear understanding of the mechanisms is lacking. ${ }^{1}$

Studies of the complement system, the principal mediator of the humoral immune system, in AS are scarce. Most studies have shown an increase of $\mathbf{C 3}$ and $\mathrm{C} 4$ levels, while the evidence for activation of complement as studied by the presence of $\mathrm{C} 3$ or $\mathrm{C} 4$ conversion products is controversial. ${ }^{2-6}$

We present the results of metabolic studies in AS patients and controls performed with purified radiolabelled C3. This factor has a central position in the complement system, as it is activated both by the classical and by the alternative pathways. ${ }^{7}$

\section{Materials and methods}

Patients and controls. Seven patients, 6 men and 1 woman, aged between 20 and 48 years, with AS

Accepted for publication 20 February 1981.

Correspondence to Dr L. Brinch, Medical Department 7 , Ullevål Hospital, Oslo, Norway. were studied. The diagnosis was made according to the New York criteria. ${ }^{8}$ All the patients were HLA B27 positive and seronegative. An attempt has been made at assessing disease activity on the basis of subjective discomfort and conventional laboratory tests, with a grading from + to +++ . Details are given in Tables 1 and 2.

Fourteen healthy medical students and medical staff, 11 men and 3 women, between the ages of 20 and 39 served as controls for the turnover data. Sera

Table 2 Conventional laboratory results relevant to disease activity

\begin{tabular}{lllll}
\hline Patient & $\begin{array}{l}\text { Haemoglobin } \\
(\mathrm{g} / \mathrm{d} l)\end{array}$ & $\begin{array}{l}\text { ESR } \\
(\mathrm{mm} / \mathrm{h})\end{array}$ & $\begin{array}{l}\text { CRP } \\
(\mathrm{g} / \mathrm{l})\end{array}$ & $\begin{array}{l}\text { Albumin } \\
(\mathrm{g} / \mathrm{l})\end{array}$ \\
\hline 1 & $15 \cdot 8$ & 22 & $<0 \cdot 01$ & 39 \\
2 & $15 \cdot 0$ & 14 & $<0.01$ & 38 \\
3 & $11 \cdot 9$ & 50 & 0.028 & 33 \\
4 & $13 \cdot 7$ & 48 & $0 \cdot 038$ & 30 \\
5 & $10 \cdot 8$ & 76 & $0 \cdot 120$ & 33 \\
6 & $14 \cdot 1$ & 31 & $<0 \cdot 01$ & 33 \\
7 & $10 \cdot 8$ & 37 & 0.015 & 32 \\
\hline Reference values & F: $11 \cdot 6-14.9$ & $3-20$ & $<0.01$ & $34-43$ \\
& M: $: 13 \cdot 2-16.6$ & $2-16$ & &
\end{tabular}

Table 1 Clinical status of the patients at the time of the study

\begin{tabular}{|c|c|c|c|c|c|}
\hline Patient & $\begin{array}{l}\text { Age } \\
\text { ( years) }\end{array}$ & $\operatorname{Sex}$ & $\begin{array}{l}\text { Duration of } \\
\text { illness ( years) }\end{array}$ & Disease activity & Treatment \\
\hline $\begin{array}{l}1 \\
2 \\
3 \\
4 \\
5 \\
6 \\
7\end{array}$ & $\begin{array}{l}34 \\
35 \\
26 \\
35 \\
20 \\
48 \\
19\end{array}$ & $\begin{array}{l}\mathbf{M} \\
\mathbf{F} \\
\mathbf{M} \\
\mathbf{M} \\
\mathbf{M} \\
\mathbf{M} \\
\mathbf{M}\end{array}$ & $\begin{array}{l}>10 \\
2-5 \\
2-5 \\
2-5 \\
2-5 \\
>10 \\
5-10\end{array}$ & $\begin{array}{l}+ \\
+ \\
++ \\
++(+) \\
+++ \\
+ \\
+++\end{array}$ & $\begin{array}{l}\text { Ibuprofen/salicylates } \\
\text { Naproxen } \\
\text { Indomethacin } \\
\text { Naproxen/prednisone } \\
\text { Indomethacin } \\
\text { None } \\
\text { Ibuprofen/prednisone† }\end{array}$ \\
\hline
\end{tabular}

* Disease activity based on subjective discomfort and laboratory parameters of acute phase activity, +++ being most active. $\dagger$ Prednisone was started on the third day of the turnover study because of acute iritis. 
from these persons were supplemented with sera from other healthy controls in the immunochemical determinations of complement component levels.

Immunochemical analyses. Clq, C3, C4, C5, and factor B levels were measured by radial immunodiffusion (RID) ${ }^{9}$ with commercial antisera (Behringwerke, Marburg/Lahn, West Germany, and Atlantic Antibodies, Westbrook, Maine, USA). The levels of $\mathrm{Clq}, \mathrm{C4}, \mathrm{C5}$, and factor $\mathrm{B}$ are given as percentages of a pooled standard from 500 blood donors. A C3 preparation made in this laboratory was used as standard for $\mathrm{C} 3$ levels.

C-reactive protein (CRP) concentrations were measured by RID with commercial antiserum (Behringwerke).

C3 and albumin turnover studies. The purification and labelling procedures of $\mathrm{C} 3$ have been described elsewhere. ${ }^{10} 11$ The turnover studies were performed as described. ${ }^{10}$ Briefly, sterile, biologically active
${ }^{125}$ I C3 was injected intravenously together with ${ }^{131}$ I albumin (Isotope Laboratories, Institute for Energy Technology, Kjeller, Norway). The plasma and urine radioactivities were measured daily for 1 week and the fractional catabolic rates (FCR) for $\mathrm{C} 3$ and albumin were calculated by the metabolic clearance method. ${ }^{12}$ The FCR for C3 was also calculated from exponential analysis of the plasma radioactivity decay curve. ${ }^{13}$ The data from the first 24 hours of each study were not used in the calculations, as these may give falsely raised values owing to the rapid removal of aggregated or denatured protein from the circulation. ${ }^{10}$ The synthesis rates (SR) of C3 were determined by means of the serum concentrations of $\mathrm{C} 3$, plasma volumes, body weights, and FCR as calculated by the metabolic clearance method.

Two batches of isolated C3 were used in the present study. Both had been tested on 1-2 normal individuals. The results of these studies fell within the normal range obtained with previous batches.

Table 3 Fractional catabolic rates of $C 3$ and albumin (per cent intravenous pool/h) and synthesis rates of C3 $(\mathrm{mg} / \mathrm{kg} / \mathrm{h})$. Probability values for difference between the patient group and the group of normal persons are given at the bottom of the Table

\begin{tabular}{|c|c|c|c|c|}
\hline \multirow{3}{*}{ Patient } & \multicolumn{3}{|l|}{$F C R(\% / h)$} & \multirow{3}{*}{$\frac{S R(\mathrm{mg} / \mathrm{kg} / \mathrm{h})}{C 3}$} \\
\hline & \multicolumn{2}{|l|}{$C 3$} & \multirow{2}{*}{$\begin{array}{l}\text { Albumin } \\
\text { metabolic clearance }\end{array}$} & \\
\hline & Metabolic clearance & Exponential analysis & & \\
\hline $\begin{array}{l}1 \\
2 \\
3 \\
4 \\
4 \\
5 \\
6 \\
7\end{array}$ & $\begin{array}{l}1.52 \\
1.76 \\
1.35 \\
1.02 \\
1.52 \\
2.38 \\
2.29\end{array}$ & $\begin{array}{l}1.06 \\
1.19 \\
0.94 \\
1.04 \\
1.14 \\
1.47 \\
1.16\end{array}$ & $\begin{array}{l}0.62 \\
0.69 \\
0.43 \\
0.32 \\
0.64 \\
0.58 \\
0.67\end{array}$ & $\begin{array}{l}0.99 \\
0.69 \\
1.26 \\
1.12 \\
2.52 \\
2.61 \\
1.61\end{array}$ \\
\hline \multirow{2}{*}{ Normals, range $(n=14)$} & $0.84-1.39$ & $0 \cdot 63-1 \cdot 19$ & $0.26-0.68$ & $0 \cdot 47-1 \cdot 15$ \\
\hline & $\mathrm{p}<0.01$ & $\mathrm{p}<0.01$ & NS* & $\mathrm{p}<0.01$ \\
\hline
\end{tabular}

* NS = not significant.

Table 4 Complement factor levels. C3 levels are given as $\mathrm{g} / \mathrm{l}$ with purified C3 as standard. Clq, C4, C5, and factor $B$ levels are given as percentages of pooled normal sera. Probability values for difference between the patient group and the group of normal persons are given at the bottom of the Table

\begin{tabular}{|c|c|c|c|c|c|}
\hline Patient & $\begin{array}{l}C 3 \\
(g / l)\end{array}$ & $\begin{array}{l}C l q \\
(\%)\end{array}$ & $\begin{array}{l}C 4 \\
(\%)\end{array}$ & $\begin{array}{l}C 5 \\
(\%)\end{array}$ & $\begin{array}{l}\text { Factor } B \\
(\%)\end{array}$ \\
\hline $\begin{array}{l}1 \\
2 \\
3 \\
4 \\
5 \\
6 \\
7\end{array}$ & $\begin{array}{l}2.05 \\
1 \cdot 35 \\
1 \cdot 72 \\
2 \cdot 44 \\
3 \cdot 14 \\
2 \cdot 53 \\
1 \cdot 53\end{array}$ & $\begin{array}{r}117 \\
94 \\
84 \\
126 \\
109 \\
99 \\
105\end{array}$ & $\begin{array}{l}175 \\
162 \\
128 \\
231 \\
203 \\
154 \\
153\end{array}$ & $\begin{array}{l}126 \\
162 \\
161 \\
211 \\
213 \\
193 \\
159\end{array}$ & $\begin{array}{l}121 \\
101 \\
152 \\
194 \\
166 \\
144 \\
117\end{array}$ \\
\hline \multirow[t]{2}{*}{ Normals, range $(n=20)$} & $0.81-1 \cdot 82$ & $73-147$ & $26-113$ & $82-165$ & $30-135$ \\
\hline & $\mathrm{p}<0.01$ & NS* & $\mathrm{p}<0.01$ & $\mathrm{p}<0.01$ & $\mathrm{p}<0.01$ \\
\hline
\end{tabular}

* NS = not significant. 
Each person was given $180-370 \mathrm{KBq}{ }^{125} \mathrm{I} \mathrm{C} 3$ and approximately $300 \mathrm{KBq}{ }^{131} \mathrm{I}$ albumin. The thyroid gland was blocked with oral potassium iodide before and during each study. Informed consent was obtained from each participant.

Statistics. Comparisons between groups were performed by the Wilcoxon rank sum test.

\section{Results}

Table 3 shows the FCR of $\mathrm{C} 3$ in the patients compared with the values found in normal persons. The patient group deviated significantly from the normals by having a higher FCR. Table 3 includes data on albumin in the same individuals. There was no significant difference in the FCR of albumin between the groups, though the turnover tended to be higher in the patients having a high FCR of C3. Table 4 shows the complement factor levels. There was a significant increase of all complement components measured with the exception of Clq.

The SR values of C3 were significantly raised in the patient group, which is shown in Table 3.

\section{Discussion}

The FCR calculated by the metabolic clearance method was higher than the value obtained by exponential analysis both in patients and controls. Our normal ranges are lower than estimations made by other authors. ${ }^{14}$ This is especially apparent when the exponential analysis is employed. These differences are mostly due to the fact that data from the first 24 hours were not used in our calculations. The risk of calculating falsely raised FCR is reduced by this procedure.

In our study the group of patients with AS had a higher catabolism of $\mathrm{C} 3$ than the normal individuals by both methods. However, some patients had a normal C3 metabolism, while the degree of elevation in FCR in the others was quite moderate. The albumin data did not indicate a higher turnover rate of proteins in general in AS patients. Thus there seems to be a specific increase in the catabolism of $\mathrm{C} 3$, compatible with an increased activation of the complement system in many AS patients. It must be emphasised, however, that our study concerns a selected patient group from a special hospital for rheumatic diseases. To our knowledge only a single patient with AS has been studied previously with regard to the in-vivo metabolism of $\mathrm{C3}^{14}$ This patient had a normal FCR and an increased SR. In seropositive rheumatoid arthritis an increase in FCR and SR was observed in some patients. ${ }^{14} 15$

The increase in FCR of C3 in our patient group is of a lower magnitude than can be seen in certain other diseases. ${ }^{16-21}$ Such a relatively modest hypercatabolism of $\mathrm{C} 3$ in AS is consistent with the chronic, long-drawn-out character of this illness, often with low-grade inflammation. Our patients were too few for valid conclusions on a possible correlation between disease activity and complement catabolism.

C3 conversion, as detected by crossed immunoelectrophoresis, has been described in AS. ${ }^{2}$ Our results are consistent with these findings. Whether the activation of $\mathrm{C} 3$ proceeds through the classical or the alternative pathway was not clarified by our study.

The raised C3 levels of our patients correspond with those reported previously. ${ }^{3}$ The increased FCR of $\mathrm{C} 3$ was thus more than compensated for by an increased synthesis rate of the protein. We have confirmed the increased $\mathrm{C} 4$ levels found by other workers. ${ }^{245}$ The possible pathogenetic significance of the increased serum protein levels remains to be elucidated.

The question of the presence and possible pathogenetic significance of circulating immune complexes (CIC) in AS is controversial. ${ }^{62-24}$ The controversy may at least in part be due to the use of different assays for CIC, and possibly to differences in the patient populations that were investigated. Our results are consistent with a pathogenetic role of such complexes, activating complement by the classical pathway and thus causing tissue damage.

Much of the current research on ankylosing spondylitis is focused on the mechanisms inherent in the association between HLA B27 and the disease. At present there are two hypotheses. The first claims that HLA B27 is associated with an immune response gene, thus leading to an altered response to certain antigens. The second hypothesis suggests that the causal agent(s) is cross-reactive with HLA B27. It is therefore not regarded as foreign by the immune system and thus not adequately eliminated. ${ }^{25}$ The present findings are perhaps more compatible with the former of the 2 hypotheses.

In summary, the complement system seems to be activated in many AS patients, supporting the view that humoral immunity may be involved in the pathogenesis of the disease. The mechanisms remain speculative.

We thank Dr Paal Möller, Institute for Medical Genetics, University of Oslo, who provided the HLA data of the patients, and the Norsk Hydro Company, which supports one of us (O. Vinje).

\section{References}

1 Mellbye $\mathrm{O} \mathbf{J}$, Vinje $\mathrm{O}$. Immunological abnormalities in Bechterew's syndrome. Primary or secondary phenomena? Scand J Rheumatol 1980; 32 suppl: 86-9. 
2 Sturrock R D, Barrett A J, Versey J, Reynolds P. Raised levels of complement inactivation products in ankylosing spondylitis. $J$ Rheumatol 1974 ; 1 : 428-31.

3 Whaley K, Canesi B, Moseley A, et al. Complement metabolism in the seronegative arthritides. Ann Rheum Dis 1974; 33: 495-9.

4 Nikbin B, Brewerton D A, Byrom N, et al. Lymphocyte function in ankylosing spondylitis. Ann Rheum Dis 1975; 34 suppl: 49-52.

5 Kinsella T D, Espinoza L, Vasey F B. Serum complement and immunoglobulin levels in sporadic and familial ankylosing spondylitis. J Rheumatol 1975; 2: 308-13.

6 Gabay R, Zubler R H, Nydegger U E, Lambert P H. Immune complexes and complement catabolism in ankylosing spondylitis. Arthritis Rheum 1977; 20: 913-6.

7 Austen K F. The classical and alternative complement sequence. In: Benacerraf B, Unanue E R, eds. Textbook of Immunology. Baltimore: Williams and Wilkins, 1979: 218-38.

8 Gofton J P. Report from the subcommittee on diagnostic criteria for ankylosing spondylitis. In: Bennett $\mathbf{P} \mathbf{H}$, Wood P H N, eds. Population Studies of the. Rheumatic Diseases. Amsterdam: International Congress Series No. 148. Excerpta Medica, 1968: 314-6.

- Mancini G, Carbonara A O, Heremans J F. Immunochemical quantitation of antigens by single radial immunodiffusion. Immunochemistry $1965 ; 2$ : 235-54.

10 Brinch L, Teisberg P, Aakesson I. Metabolic studies of C3 in man. J. Immunol Methods 1979; 30: 69-75.

11 Brinch L, Aakesson I. Aseptic isolation of human complement component $\mathrm{C} 3$ for in vivo studies. Scand J Clin Lab Invest 1980; 40: 487-9.

12 Berson S A, Yalow R S. Distribution and metabolism of I $^{131}$ labelled proteins in man. Fed Proc 1957; 16: 13S$18 S$.

13 Matthews C M E. The theory of tracer experiments with 131I labelled plasma proteins. Phys Med Biol 1957; 2: 36-53.

14 Ruddy S, Carpenter C B, Chin K W, et al. Human complement metabolism: an analysis of 144 studies. Medicine 1975; 54: 165-78.

15 Weinstein A, Peters K, Brown D, Bluestone R. Meta- bolism of the third component of complement (C3) in patients with rheumatoid arthritis. Arthritis Rheum 1972; 15: 49-56.

16 Charlesworth J A, Williams D G, Sherington E, Lachmann P J, Peters D K. Metabolic studies of the third component of complement and the glycine-rich beta glycoprotein in patients with hypocomplementemia. $J$ Clin Invest 1974; 53: 1578-87.

17 Potter B J, Elias E, Anthony Jones E. Hypercatabolism of the third component of complement in patients with primary biliary cirrhosis. J Lab Clin Med 1976; 88: 427-39.

18 Petz L D, Pomers R, Fries J R, Cooper N R, Holman $H R$. The in vivo metabolism of the third component of complement in systemic lupus erythematosus. Arthritis Rheum 1977; 20: 1304-13.

19 Hodgson H J F, Potter B J, Jewell D P. C3 metabolism in ulcerative colitis and Crohn's disease. Clin Exp Immunol 1977; 28: 490-5.

20 Thomas H C, Potter B J, Elias E, Sherlock S. Metabolism of the third component of complement in acute type $B$ hepatitis, HBs antigen positive glomerulonephritis, polyarteritis nodosa, and HBs antigen positive and negative chronic active liver disease. Gastroenterology 1979; 76: 673-9.

21 Brinch L, Teisberg P, Fausa O, Aakesson I. The metabolism of C3 in adult coeliac disease. Scand J Gastroenterol 1980; 15: 33-8.

22 Corrigall V, Panayi G S, Unger A, Poston R N, Williams B D. Detection of immune complexes in serum of patients with ankylosing spondylitis. Ann Rheum Dis 1978; 37: 159-63.

23 Laurent M R, Panayi G S, Alexander M. Circulating immune complexes in ankylosing spondylitis. In: Peeters $\mathrm{H}$, ed. Protides of the Biological Fluids. Oxford: Pergamon Press, 1978: 26: 167-70.

24 Duquesnoy B, Santoro F, Delcambre B, Wattre P. Absence des complex immuns circulants et d'anticorps anti-IgG sériques au cours de la spondylarthrite ankylosante. Rev Rhum Mal Osteoartic 1979; 46: 397-401.

25 Editorial: Klebsiella and ankylosing spondylitismolecular mimicry? Lancet 1979; i: 1012-3. 